\title{
The Herald's Portrayal of School Violence in the Eastern Cape Province, South Africa
}

\author{
Corene De Wet \\ School of Open Learning, University of the Free State, Bloemfontein, South Africa \\ Email: dewetnc@ufs.ac.za
}

\section{Doi:10.5901/mjss.2014.v5n16p490}

\section{Abstract}

This study explores The Herald's portrayal of school violence in the Eastern Cape Province (ECP), South Africa. The article, therefore, sets out to report on findings from a qualitative content analysis of 28 news articles and one letter to the editor retrieved from the SAMedia database. The findings shed light on the victims and their victimisation, the perpetrators, as well as the space and locality of school violence. The study identifies demands to and dissatisfaction with the education authorities, educators' behaviour, the conduct and psyche of learners, the learners' home environment, as well as the socio-economic and cultural factors as reasons for violence in ECP schools. The study highlights the negative consequences of school violence on teaching and learning and the economy. The study underlines the importance of involving educators, parents, police services and the community in addressing the problem. It is concluded that although The Herald's atypical and stereotypical portrayal of the phenomenon may create the impression that school violence is endemic in the ECP, previous research on the topic shows that ECP schools are relatively safe places.

Keywords: education; media analysis; South Africa; school violence

\section{Introduction}

The news media, by aiming to disseminate news to listeners, viewers and readers, raises public awareness of what they perceive to be a problem and thereby sell their advertisers' products (Jacobs, 2014; Leavy \& Maloney, 2009). The frequency, depth and importance given by the media concerning an issue are believed to determine the level of observation, the reaction or the thoughts of the targeted audience or society towards it. The media's depiction of events can impact on the causal reasoning employed by the public by emphasising particular attitudinal or behavioural linkages of cause and effect. Consequently, coverage and portrayals of social problems, such as school violence in the media, are important because they help to create the perception of the risk and willingness to support an investment of resources in prevention and intervention (De Wet, 2011). The regularity with which newspaper articles on school violence appear confirms that school violence is a newsworthy problem that needs to be addressed (Jacobs, 2014; Mills \& Keddie, 2010). Front-page headlines proclaiming "Our schools are war zones" (Roelf \& Sonjica, 2006:1), "Teen fights for his life after school stabbing" (Jack, 2006:1), "Violent pupils terrorising Mandela Bay bus drivers" (Adkins, 2007:1) and "Exam violence grows as tyres burnt, cars stoned" (Wilson \& Matomela, 2010:1) bring school violence in the Eastern Cape Province (ECP) into the homes of the readers of The Herald, a regional newspaper published in Port Elizabeth.

The media's presentation of these atypical events as stereotypical (symptomatic of a culture of violence and the disintegration of schooling in the ECP) (Muncie, 2012) may well create the perception that school violence in the ECP is out of control. To present a balanced picture of school violence in the ECP, findings emanating from a media analysis should therefore be juxtaposed with results from previous research (e.g. Burton \& Leoschut, 2013; Jacobs, 2014).

The overarching aim of this study is to gain insight into The Herald's portrayal of school violence in the ECP. To reach this aim and further the content analysis, the following sub-questions were posed:

- What is the nature and context and who are the role-players of school violence in the ECP?

- What are the reasons for school violence in the ECP?

- What are the consequences of the violence?

- What can be done to address the problem?

\section{Concept Clarification}

Researchers studying school violence have found that there is no clear definition as to what constitutes school violence (De Wet, 2011; Jacobs, 2014). Jacobs (2014:2) gives the following detailed definition: 


\begin{abstract}
School violence refers to any intentional use of physical or other force of power, threatened or actual, against oneself, another person, or against a group, at school, that either results in or has the likelihood of resulting in injury, death, psychological harm, maldevelopment, or deprivation. It thus includes any intended use of psychological power or physical force with the aim to harm another physically or emotionally. It includes manipulation and coercion as well as rejection, and can take place during or outside school hours, during class times and breaks, at school related events (sports, cultural and social), as well as while commuting to and from school.
\end{abstract}

Violence in the school context can range from psychological to physical forms of violence, including hazing or initiation, assault (physical or sexual), robberies, rape, murder, sexual harassment, intimidation, bullying, shootings, stabbings, gangsterism, drug trafficking, theft of property and vandalism, racially motivated violence and learner protests that turn violent (SACE, 2011).

\title{
3. Research on Newspapers' Portrayal of School Violence
}

A small, but growing body of research on the media's reporting of school violence has attracted the attention of researchers (De Wet, 2011; Muncie, 2012). The topic has been addressed from different angles, including comparative analyses of the media's portrayal of school shootings in three urban and three rural settings in the USA (Menifield, 2001), as well as the Columbine and Red Lake school shootings (Leavy \& Maloney, 2009), discourses around schools, violence and masculinity (Mills \& Keddie, 2010), and the gendered discourses in two Finish newspapers' reporting of two school shootings in Finland (Kantola, Norocel \& Repo, 2011).

Studies focusing on the media's reporting of school violence in South Africa are limited. Jacobs's (2014) framing analysis of 92 newspaper articles revealed that the way in which the public is informed about school violence encourages the perception of school violence as an individual, rather than a societal problem and encourages the acceptance of assumptions and stereotypes. Content and framing analysis of the Krugersdorp samurai sword killing by De Wet (2011) highlighted the conflicting portrayal of the perpetrator, his parents and the school where the killing took place. In a qualitative content analysis of newspaper articles on school violence published between June and September 2008, De Wet (2009) focused on how victims and perpetrators are portrayed in the South African printed media.

\section{Research on School Violence}

School violence has received the attention of international (e.g. Astor, Benbenishty, Vinokur, \& Zeira, 2006; Muncie, 2012:161-178; Shawhacker, 2002) and South African researchers (e.g. Mkhize, Gopal \& Colling, 2012; Van der Merwe, 2010; Van der Westhuizen \& Maree, 2009). With a few exceptions, such as the studies by Barnes (2010), Burton (2008), Burton and Leaoschut (2013), the South African Human Rights Commission (SAHRC) (SAHRC, 2008) and Jacobs (2012), research on the topic within the South African context is of limited scope and predominantly localised (De Wet, 2003; Mkhize et al., 2012; Van der Merwe, 2010; Van der Westhuizen \& Maree, 2009). Despite the localised character of research on school violence in South Africa, little evidence could be found of publications that focus solely on school violence in the ECP (Barnes, 2010; De Wet, 2003). Three publications on school violence were identified that give cursory attention to the phenomenon in the ECP as one of three (Jacobs, 2012) or one of the nine provinces (Burton, 2008:8; Burton \& Leoschut, 2013:12) in South Africa.

Some of the data reported on by Burton (2008:8), Burton and Leoschut (2013:12) and Jacobs (2012) place the problem in ECP within the broader South African context. Burton (2008:8) conducted a study among 12794 learners, 260 school principals and 521 educators in South Africa. This study was followed up in 2012 by a survey among 5939 learners, 121 school principals and 239 educators in all nine provinces in South Africa (Burton \& Leoschut, 2013). Whereas the 2008 study investigated violence among primary and secondary school learners within the school yard during the 12 months preceding the study, the 2012 study focused on secondary school learners (Burton, 2008; Burton \& Leoschut, 2013). Using data from the questionnaires completed by the learners, Burton and Leoschut (2013) found that a total of $22.2 \%$ of the learners experienced threats of violence, assault, sexual assault and robbery. This percentage was up $0.2 \%$ from the $22 \%$ observed in Burton's (2008) previous study. Burton and Leoschut (2013) found that seven out of the nine provinces had provincial violence rates that exceeded the national average of $22.2 \%$. Only Gauteng and the ECP had violence rates that were less than the national average. Jacobs's (2012:198) study focused on school violence in the ECP $(n=202)$, the Free State Province $(n=329)$ and the Gauteng Province $(n=159)$. She found that the levels of violence in the ECP were statistically significantly higher than the other two provinces.

The following percentages from Burton and Leoschut's (2013) study give the comparative experiences of violence 
in the ECP during 2012 and 2008 (percentages for 2012 are indicated first): threats of violence 10.3\% versus 6.6\%; assault $3.3 \%$ versus $2.3 \%$; sexual assault $3.6 \%$ versus $1.5 \%$; robbery $3.3 \%$ versus $3.4 \%$; theft $55.9 \%$ and $29.6 \%$. With the exception of robbery, there seems to be an increase in all types of crime activities assessed in the ECP. De Wet (2003) investigated ECP educators' $(n=215)$ perceptions of the causes and the scope of school violence. Results from her study will be reported on in more detail in Section 6 of this paper. Using an education management perspective, Barnes (2010) explored the influence of school culture and school climate on violence in ECP schools ( $n=900)$. His study however, does not give insight into the nature and extent of the violence in the ECP.

\section{Research Methodology}

\subsection{Data selection}

I used articles published in The Herald as textual data to explore school violence in the ECP. Newspaper articles offer qualitative data that do not depend on the support of the participants, are not produced for research, and are not influenced by the presence of the researcher. Newspaper articles which are electronically available provide data that are accessible to others and are easy to obtain (Jacobs, 2014; Merriam, 2009). In order to convey an extensive picture of violence in ECP schools, news and in-depth informative articles, editorials, and letters to the editor related to violence in South African schools and school hostels that were published in The Herald over a period of eleven years (1 January 2002 to 31 December 2012) were retrieved from the SAMedia database (http://www.samedia.uovs.ac.za/). Only one keyword, namely 'violence', was used to search for articles in the education section of the databases. SAMedia classify newspaper articles that make reference to physical injuries, weapons and/or police intervention under the keyword 'violence'. Articles filed under violence related keywords, e.g. sexual harassment, robberies and bullying were thus not taken into consideration for this study (De Wet, 2009). From the ensuing discussion it will become evident that some of the retrieved articles also refer to activities, such as drug and alcohol abuse, as well as vandalism.

The full-text keyword search yielded 45 items on violence published during the abovementioned period. Among the 45 items, 28 were news articles, five editorials, six in-depth informative articles written by experts (e.g. Kollapen, 2006) and six letters to the editor. In line with the aim of this study, i.e. to gain insight into The Herald's portrayal of school violence in the ECP, my data set was the 28 news articles and one letter to the editor. In this letter a witness describes an altercation between learners (Henry, 2007).

\subsection{Data analysis}

Content analysis, a systematic approach to qualitative data analysis, was used to identify and summarise the content of the news articles and a letter to the editor. I followed Nieuwenhuis's (2007) guidelines for qualitative content analysis in order to reduce, condense and group the content of all the articles and the letter. A coding frame was drawn up, also providing for verbatim reporting where applicable. I used preset codes (a priori coding) that I identified whilst doing the literature review for my study. I worked though all my data sources and coded all the data. Related codes were thereafter organised into preset categories (cf. research questions). These preset categories were identified whilst doing my literature review. After I had completed my categorisation, I reread the news articles and the letter to check whether I had captured all the important insights that emerged from the data. From the categories, patterns and themes which could be linked to the research questions, were identified and described. The identification of emergent themes allowed the information to be analysed and related to the literature.

To enhance the integrity of the study, I used documents that are authentic (scanned-in, unedited versions of the original newspaper clippings, the publication date and the page on which the article appeared) and left an audit trail by giving the website address of SAMedia and the word used for the electronic search. I also described the research process in relative detail, linked the data to the existing literature on the topic and gave rich, thick descriptions to allow transferability (Jacobs, 2014; Nieuwenhuis, 2007).

\section{Findings and Discussion}

Newspapers move beyond the mere dissemination of information. They strive to educate their readers about important social issues. In the next section, attention will be given to the themes identified in the newspaper articles and in the letter to the editor. I will integrate my findings with prior research. The practice of concurrently presenting findings from prior and current research is an accepted mode of reporting in qualitative research (Nieuwenhuis, 2007). 


\subsection{The nature, context and role-players of school violence}

\subsubsection{The victims and their victimisation}

An analysis of the data set reveals that a wide variety of acts of violence were perpetrated against the Department of Basic Education (DBE), educators and other adults, learners and property. In the ensuing discussion, I will highlight the different types of violence committed against the different groupings of victims.

\subsubsection{Acts of violence directed at the DBE}

In several newspaper articles the DBE was identified as the main target for learners, parents and educators to vent their frustration and anger. Efforts by those infuriated lead to violent skirmishes between members of the public, clashes with the South African Police Services (SAPS), and marches characterised by the vandalism of public and private property. The following examples will suffice: In an effort to vent their anger on and frustration against the DBE at the dilapidation of their children's school, "angry" parents "stormed" into a school's premises, went into classrooms and ordered their children out (Jack, 2008:5). Two "opposing groups of hundreds" of learners and parents engaged in a "bloody stonethrowing skirmish" in a school's yard (Matyu, 2005:9). In 2010, 5000 learners marched to provincial education buildings. The learners damaged police cars, set tyres alight and placed boulders in the road. These protesting learners also resorted to throwing stones and bottles filled with water at police and passing motorists (Wilson \& Matomela, 2010). In 2012 parents, educators and learners joined forces to protest against "empty promises" by the DBE. The protesters threw stones, burned tyres and toytoyed (Mbabela, Williams \& Reyneke, 2012:1).

\subsubsection{Violence against educators and other adults}

This study found that educators are often the victims of learner-on-educator violence. Newspaper reports make mention of learners throwing eggs at their educators (Matomela, 2008a), learners keeping educators captive (Matomela, 2009) and a learner threatening to shoot an educator (Matyu, 2007). It is furthermore suggested that educators fear for their lives when they disarm learners carrying weapons and "all sorts of weaponry" in schools (Masondo, 2006:3). Educators were also attacked and robbed on their way to and from school (Matyu, 2002a; Roelf \& Sonjica, 2006). These findings are confirmed by previous research. School principals and educators who took part in Burton and Leaoschut's (2013) survey believe that educators feel unsafe while at school. Burton and Leaoschut (2013) furthermore found that educators fairly often report incidents of learners being verbally abusive towards them (52.1\%), and physically (12.4\%) or sexually (3.3\%) assault them. SAHRC (2008) likewise, found that educators are the victims of verbal and physical abusive learner behaviour. In my previous study on violence in the ECP (2003), I found that ECP educators were victims of gang fights (17.2\%), robberies (35.4\%) and rape by colleagues (11.2\%) and learners (12.6\%). They were also assaulted (67\%) and bullied (34\%) by their learners (De Wet, 2003).

Acts of violence by learners against adults were however, not confined to their educators, but also directed at bus drivers and other adults with no direct link to the attackers and their schools. Mandela Bay bus drivers were, among other things, verbally abused, stabbed in the shoulder, robbed and assaulted (slapped across the face) by learners (Adkin, 2007). In December 2003 nine schoolboys allegedly took part in an "unprovoked ... alcohol-fuelled attack" on a group of adults from the World of Faith Christian Centre (Matavire, 2003:3).

\subsubsection{Violence against learners}

The Herald reported on different types of learner-on-learner violence. News articles make mention of learners stabbing one another with knives (McCabe, 2007; Ndabeni, 2009; Mofemele, 2007; Nofemele, 2006) and scissors (McCabe, 2007) and learners hitting one another with iron pipes (Spies, 2006; Wilson, 2012) and small rocks (Henry, 2007). Learners were also involved in fist fights (Henry, 2007; Rank, 2005; Spies, 2006; Timse, 2006). A learner was shot in the neck by a fellow-learner (Dimbaza, 2009). Although the aforementioned incidents resulted in the hospitalisation of the victims, none of the altercations was fatal. However, Matyu (2007) reports on the fatal stabbing of a Grade 11 boy. A girl from East London died after a fist fight (Masondo, 2006). An 18-year old Grade 10 learner was stabbed to death by three fellowlearners during a school event at a community hall (Mofemele, 2007). These findings are in line with previous research on school violence in South Africa. The SAHRC (2008) and the SACE (2011) found that learners are assaulted with fists and sharp objects, are bitten and also sustain wounds related to the use of firearms. They also found evidence that learners 
are raped and assaulted by fellow-learners.

Evidence was also found of educators and other staff members' abusive and uncaring actions towards learners. Boarding school learners at Khanyisa School for the Blind were left to "fend for themselves" when the institution was temporarily shut by education officials. This left learners unsupervised and hungry (Matomela, 2009:5). The above quoted article is the only retrieved article that mentions educators' abusive behaviour towards learners. However, researchers have exposed the seriousness of educator violence in South Africa. Educators who took part in De Wet's (2003) study indicated that ECP learners were raped (17.2\%) and assaulted by their educators (41.4\%). In Burton and Leaoschut's (2013) nationwide study, educators were identified as perpetrators in $25 \%$ of assaults reported, $9.1 \%$ of robberies, $6.9 \%$ of thefts and $6.8 \%$ of cases in which learners had been threatened with harm while at school. Educators were furthermore identified as the aggressors in 3.9\% of sexual assaults. More than half of the learners who took part in Jacobs's (2012) study, namely $59.6 \%$, indicated that they were victims of educator-on-learner violence.

None of the retrieved newspaper articles made mention of incidents of corporal punishment in ECP schools. It should however be noted that in some of the articles there was an appeal for the reinstatement of corporal punishment (cf. 6.2). Researchers perceive corporal punishment as a form of violence (SAHRC, 2008). A nationwide study by Burton and Leaoschut (2013) has found that corporal punishment is common in South African schools: $49.8 \%$ of their learnerrespondents claimed that they had been caned or spanked by an educator or principal as punishment for wrongdoings. Burton and Leaoschut (2013) note that this percentage was up from $47.5 \%$ from Burton's (2008) previous study. The ECP rates for corporal punishment increased from 58.5\% in 2008 to $66.9 \%$ in 2012 (Burton \& Leaoschut, 2013).

This study furthermore found that learners are sometimes the victims of violence from individuals with no direct link to education. Roelf and Sonjica (2006), as well as Matyu (2002a) report on learners being robbed and attacked on their way to and from school. They were robbed of jewellery, cell phones, taxi fares and lunch money. Circumstances may lead to unintentional acts of violence against learners by members of SAPS: during the 2010 protest marches the police fired rubber bullets and shot stun grenades to disperse crowds, which included learners (Wilson \& Matomela, 2010).

\subsubsection{Perpetrators of school violence}

The above exposition of the victims and their victimisation alluded to the identity of the perpetrators. The following summary of the perpetrators will therefore be deemed sufficient: individuals, be it parents (Jack, 2008), learners (Dimbaza, 2009; Matomela, 2008a), "community" friends avenging the violent death of a learner (Mofemele, 2007:4), learners who are members of opposing gangs (Ndabeni, 2009) or educators (Matomela, 2009), are involved in school violence. There is also evidence of groups acting aggressively, such as 5000 marching learners (Wilson \& Matomela, 2010), educators (Mbabela et al., 2012) or parents storming into a school (Jack, 2008). Sometimes these three groups formed alliances and marched into the DBE's offices in unity (Mbabela et al., 2012). Learners and educators were also accosted by "thugs roaming the streets" on their way to and from school (Matyu, 2002a:8). These findings, namely that acts of violence are committed by a variety of perpetrators, are confirmed by previous research (SAHRC, 2008). Burton and Leaoschut (2013:41) furthermore found that small percentages of family members, "people of authority", persons from outside the school and gang members are responsible for attacks against learners.

Jacobs's (2012) and De Wet's (2003) research finding, namely that learners are the main perpetrators of school violence, is suggested by the preceding data. De Wet's (2003) study, which focuses on the ECP, revealed that learners were involved in gang fights (44.2\%), were raped (31.6\%), assaulted (31.6\%) and bullied (71.6\%) by fellow-learners. Burton and Leaoschut (2013) found that the identified perpetrators of threats (90.3\%), assaults (96.8\%), sexual assaults $(90.9 \%)$, robberies (86.0\%) and thefts (91.3\%) committed against learners in South African schools were fellow-learners. While only one of the retrieved articles made mention of educator-on-learner abuse (Matomela, 2009), the SAHRC (2008) and De Wet (2003) found that South African learners are subjected to sexual violence, sexual harassment and physical assault by their educators.

\subsubsection{The space and locality of school violence}

The acts of violence in the ECP take place in a variety of settings; for example, in classrooms (Roelf \& Sonjica, 2006; Spies, 2006), on school premises (Masondo, 2006), in school hostels (Matomela, 2009), to and from schools (Matyu, 2002a; Matyu, 2002b; Roelf \& Sonjica, 2006), on buses (Adkin, 2007), in public spaces (e.g. during protest marches (Wilson \& Matomela, 2010), at Shark Rock Pier (Matavire, 2003), at a community hall (Mofemele, 2007)), as well as on sports fields (Rank, 2005). The foregoing findings, namely that school yards and public places frequented by learners, are not safe, is confirmed by Burton and Leaoschut's (2013) nationwide and De Wet's (2003) ECP studies. Note should be 
taken of Burton's (2008) finding, namely that the classroom is the place where most incidents of school violence take place. According to the learners who took part in his study, educators tend to leave classes unsupervised. This creates an opportunity for violence to transpire. De Wet (2003) additionally found that only $16.3 \%$ of learners feel safe in the classroom whilst the educator is present.

It furthermore seems as if no type of school is unaffected by school violence. The following will suffice: acts of violence take place in primary and secondary (Maryu, 2005), as well as rural and urban schools (Matyu, 2002a). The Herald reported on acts of violence at a school for partially-sighted learners (Matomela, 2009), the Bergsig Special School in Uitenhage (Wilson, 2012), in the townships (Matomela, 2008a), as well as in former model C schools (McCabe, 2007). Schools with standing in the community, for example, a "top New Brighton school" (Dimbaza, 2009:1) and "two leading Port Elizabeth schools" (Rank, 2005:10) are also mentioned. Burton and Leaoschut's (2013) study quantify the foregoing finding, namely that violence in South Africa is significantly more prevalent in schools located in urban (26.2\%), compared to those in metropolitan (21.7\%) and rural areas (20.8\%; $p<0.05)$. Jacobs (2012) and Barnes (2010) however, found that the levels of violence are higher in rural than in urban schools. Jacobs (2012) on the other hand, found that learners from more affluent areas experience higher levels of violence than those attending less affluent schools.

\subsection{The reasons for the violence}

Demands to and dissatisfaction with the ECP DBE, educators' behaviour, the conduct and psyche of learners, the learners' home environment, as well as socio-economic and cultural factors were identified as possible reasons for school violence in the ECP. In the next description attention will be given to these reasons. I will also show that acts of violence sometimes erupt without any obvious reason.

An analysis of the newspaper articles reveal that the violent protests against the DBE is a fairly common occurrence in the ECP. Parents who entered the school premises at a school in Greenbushes wanted to show their frustration and anger about what they perceive to be the DBE's unwillingness to repair dilapidated classrooms (Jack, 2008). In 2012 violent protests erupted in several education districts because of a shortage of educators, delays in the appointment of temporary, as well as permanent educators, and the non-payment of existing temporary educators (Mbabela et al., 2012).

In several of the newspaper articles educators are portrayed as the scapegoats for the violence. They are mostly blamed for a lack of action. It is suggested that educators' unwillingness to stand up against violence, perpetuate it. A report by Ndabeni (2009:1) alludes to a conversation of a victim of a gang related attack and his brother with educators. The educators allegedly told the victim and his brother that "they did not interfere with things that happened outside school. 'My brother told them my attacker was wearing a school uniform and that the incident happed during school time. The teacher told us to sort the matter out among ourselves'". Another victim's family criticised a school for not having effective safety measures in place (Ndabeni, 2009). The data furthermore revealed that educator strikes may be a reason for violence. Learners who took part in a protest march that turned violent demanded that Grade 12 examinations be postponed. They argued that they were ill prepared due to the educator strikes (Wilson \& Matomela, 2010). It was also suggested that educators' inability to instil a disciplined learning milieu may create an environment that encourages school violence. Parents and educators told reporters (Matomela, 2008a; Matyu, 2007) that the banning of corporal punishment should be blamed for learners' violent behaviour. This argument is however rejected by members of the academe (De Waal, Curie \& Erasmus, 2000; Van Jaarsveld, 2008). These researchers argue that school violence is perpetuated by corporal punishment. Research supports the notion that a lack of pro-active measures to deter, as well as an indifferent attitude towards violence perpetuates violence (De Wet, 2003; SAHRC, 2008).

A fight over a cell phone's memory card (Dimbaza, 2009) and the slapping of a bus driver by a boy who refused to pay for his ride (Adkin, 2007) suggest that learner greed and criminality may lead to school violence. It should furthermore be noted that seemingly innocent mocking may escalate into violence and that people are attacked by learners without any obvious reason. A boy was, for example, stabbed in the neck by a friend after a "playful jibe" escalated into an argument and then a violent fight (Jack, 2006:1). Learners furthermore condone and perpetuate violence by distributing electronically recorded acts of violence on social media. Timse (2006) reports on a fist fight between two Grade 11 girls from a Port Elizabeth school which was filmed on a cell phone. A video, in three parts, is distributed at R5 per text message. A spokesperson for the Angola Bus company, whose bus drivers have been subjected to verbal and physical attacks, told Adkin (2007:1) that "the young man stood behind the driver and suddenly stabbed him in the shoulder - it was totally unprovoked". The underlying reason for playful mocking turning into violence, the filming and distribution of recordings of an altercation and the senseless attack on a bus driver may well be found in the culture of violence prevailing in South Africa. The data thus suggest that peer relations, a lack of social skills, moral degradation and a 
culture of violence among learners may be reasons for school violence. This is in line with previous research (De Wet, 2003; Jacobs, 2012; SACE, 2011).

Reasons for school violence are not restricted to the education milieu. Paul Coldiz, president of the Federation of Governing Bodies of South African Schools told Matomela (2008a) that a lack of parental care and the disintegration of family lives should be blamed for learners' violent behaviour. This argument is supported by research (Barnes, 2010; Burton \& Leaoschut, 2013; De Wet, 2003; Mkhize et al., 2012).

An analysis of the data identified societal factors that may contribute to school violence. In several newspaper articles it was suggested that community violence may spill over into schools. A principal told Nofemele (2006:1) that "there were social problems in the community. There is a tavern nearby. Some of the pupils are able to buy cigarettes over the school fence. It is difficult for teachers to control that." It was also suggested that gangsterism (Ndabeni, 2009), poverty (Adkin, 2007), as well as drug, alcohol and child abuse (Matavire, 2003; Roelf \& Sonjica, 2006) may lead to school violence. The finding that community related factors contribute to school violence is confirmed by previous research (Barnes, 2010; Burton \& Leaoschut, 2013; De Wet, 2003; SACE, 2011; Van der Westhuizen \& Maree, 2009). Researchers (De Wet, 2003; Van der Westhuizen and Maree, 2009; Van Jaarsveld, 2008) argue that school violence in South Africa is exacerbated by the growing rate of poverty. Barnes (2010) and De Wet's (2003) studies on the ECP make specific reference to the influence of gangsterism in the community and the school on school violence. Relatively large percentages of the ECP learner-respondents who took part in Burton and Leaoschut's (2013:55) survey indicated that "crime is common in my neighbourhood" (51.2\%) and have witnessed physical attacks in their neighbourhood (47.5\%). The SACE (2011) warns that high levels of violence in South African communities, and learners' exposure to these acts, may result in the normalisation of violence. Van Jaarsveld (2008:179) writes in this regard that learners are "only modelling out what they see at home and in their communities, which leads them to also use violence as a method of resolving issues".

An article by Matomela (2008b) illustrates the role of cultural factors on school violence. Matomela (2008b:1) reports that schools claim that "they have been hit by a storm of unruly and violent pupils who believe they are invincible after paying sangomas to contaminate them with 'evil powers'". Evil spirits, commonly known as Amakhosi, have allegedly being transferred into learners, causing them to run amok at their schools. The learners believe that the Amakhosi make them invincible. Consequently, they assault fellow-learners, because they want to "test the strength of the Amakhosi".

\subsection{The consequences of school violence}

The literature and findings from this study are in agreement that school violence has dire consequences for teaching and learning. After discussing the impact of school violence on learners and educators, I will briefly refer to the possible impact of violent school marches on the economy.

Several news articles make mention of the negative consequences of school violence on schooling. Jack's (2008) article mentions, for example, that parents stormed onto the school premises and ordered learners out of the classrooms. Learners moreover miss classes to take part in protest marches (Mbabela et al., 2012; Wilson \& Matomela, 2010), or when they are under police custody (Dimbaza, 2009; Jack, 2006), suspended (Matomela, 2008a) or in hospital recovering from serious injuries (Dimbaza, 2009; Spies, 2006; Wilson, 2012). Schools are sometimes forced to close early "for the safety of teachers and their pupils" (Matyu, 2002b:1). School violence may furthermore lead to emotional problems in learners, resulting in learning difficulties (Roelf \& Sonjica, 2006) or indifference (Mbabela et al., 2012). These findings are supported by researchers such as Astor et al. (2006) and Van der Westhuizen and Maree (2009) who emphasise the negative impact of school violence on learners' concentration span, motivation, ability to acquire numeracy and literacy skills, handle assignments, perform during assessment activities, school attendance and dropout rates. Contrary to these findings, the majority of learners who took part in Burton and Leaoschut's (2013) study and who have experienced violence reported that the incident had no negative impact on their school attendance, concentration or marks. This notwithstanding $17.4 \%$ of the victims of violence reported missing school once or twice as a result of a violent incident, while $4.5 \%$ of learners had missed school a few times. In addition 13\% of victims reported that their marks dropped in the short term as a direct result of the violence, while significantly fewer (4.8\%) reported that their marks dropped for a while or "a few times" after the violent incident (Burton \& Leaoschut, 2013).

It also become clear from the newspaper articles that school violence results in low staff morale (Roelf \& Sonjica, 2006) or educators deciding to "withdraw their labour for a day to protest the situation [violence and vandalism in schools]" (Matyu, 2002b:1). The negative impact of school violence on the morale of educators and on their time to educate is summarised by the provincial chairperson of a teachers' union. He told Masondo (2006:3) "Our schools are 
very dangerous today. We are police officers, as well as everything else in our schools today". These findings resonate well with findings from previous research (SAHRC, 1008; Van der Westhuizen \& Maree, 2009). Burton and Leaoschut (2013), and the SAHRC (2008), when referring specifically to violence directed at educators, note that fearing for one's safety at school may have negative implications, such as a lack of commitment to school, poor school attendance and poor relationships with learners. These may impact negatively on the quality of teaching.

School violence has direct and indirect economic costs for the community. Protesters vandalised cars and damaged roads by setting tyres alight (Wilson \& Matomela, 2010). Wilson and Matomela (2010) mention that shopping complexes sometimes close their doors when they know protest marches are going to take place. The managers/owners of businesses operating in these complexes fear theft and vandalism.

\subsection{What can be done to stop the violence?}

A golden thread that links the suggestions on how to curb violence in ECP schools is the argument that educators, parents, police services and community leaders should work together to address the problem.

The spokesperson of a bus company whose drivers were attacked and robbed by learners, appealed to the public to assist them in curbing violence on their buses: "We appeal to the public to be our eyes and ears so that we can work together towards preserving these buses" (Adkin, 2007:1). The idea that the community should take responsibility for the safety of the learners and curb violence was also verbalised by the then Minster of Education, Naledi Pandor (quoted in The Herald, 2006:8) when she said that "all must act ... in union" to ensure that anti-social behaviour has no place in education. Expanding on Pandor's speech The Herald (2006:8) suggested a "neighbour watch system of patrols, the escorting of children to and from school and a programme to inculcate into the community that the school is an asset that is the property of all".

Some acts of school violence are punishable by law (cf. McCabe, 2007; Matomela, 2009; Mofemele, 2007; Ndabeni, 2009; Nofemele, 2006; Wilson \& Matomela, 2010) and intervention by SAPS is therefore inevitable. It seems as if the role of the police is perceived to be preventative, rather than punitive: "The police should run a moral regeneration programme for schools" (Roelf \& Sonjica, 2006:1). Interviewees furthermore suggested community policing, random searches for weapons by SAPS (Mofemele, 2007) and heightened security by police (Nofemele, 2006). It is also suggested that the SAPS's efforts should be supported by the increased vigilance of educators (Nofemele, 2006) and information sessions presented by social workers (Mofemele, 2007).

The abolition of corporal punishment was mentioned in two newspaper articles as a reason for school violence (Matomela, 2008a; Matyu, 2007). It is therefore understandable that the reinstatement of this banned practice was offered as a solution for violence. Matyu (2007:8) writes that the South African Schools Act (1996), which abolished corporal punishment, left educators "helpless, knowing even a smack or suspension of a rebellious pupil could land them in a court of law charged with abuse or violation of the Act". Whereas Matyu is in favour of punitive measures to curb violence, Craig Arendse, Mediation and Transformation Practice manager suggests workshops to transform the culture of violence in schools (cf. Timse, 2006). The latter view is supported by research. SACE (2011:6) recommends, for example, "the provision of alternatives to corporal punishment", such as conflict resolution skills and more pro-social ways of dealing with conflict.

School violence is a reality in the ECP. To proclaim, like the principal of a Humansdorp school, after a stabbing incident, that "we were totally unprepared because it has never happened before" (Nofemele, 2006:1) is not acceptable. This study has shown that the DBE, learners, educators, parents, members of the community, socio-cultural and economic factors may all be held responsible for school violence. A multidimensional approach to school violence is therefore imperative. Burton and Leaoschut (2013) urge schools to follow the DBE's framework for a whole-school approach in addressing school violence. They stress that the planning of the school safety plan and strategy should be "integrated into local development and safety plans, ensuring partnerships with other relevant stakeholders, with clear lines of responsibility and accountability defined" (Burton \& Leaoschut, 2013:103). The SAHRC (2008) and SACE (2011) give detailed recommendations on how to curb violence in schools. The SAHRC's (2008) report emphasises the need to make the school environment a safe place, train and support educators to deal with violence, advance a culture of peace through a curriculum of non-violence, and increase the involvement of parents, School Governing Bodies and communities. The SAHRC (2008) furthermore emphasises the need for research on the trends of violence in South Africa's schools, and the development of laws and policies on local and national levels. These recommendations by Burton and Leaoschut (2013), SACE (2011) and the SAHRC (2008) correspond with findings from this study, namely, that there should be a holistic approach towards school safety and that the community should play a key role in this regard. 


\section{Concluding Remarks}

Findings from this qualitative content analysis of news articles and a letter to the editor published in The Herald over a period of eleven years creates the impression that school violence is a serious problem in the ECP. The study reveals that the DBE, learners, educators, parents and members of the community are exposed to a wide range of emotional and physically destructive behaviour within and outside the school yard. Issues pertaining to the DBE, educators' behaviour, the conduct and psyche of learners, learners' home environment and the moral decay in the community were identified as reasons for school violence. The role of socio-economic and cultural factors in the perpetuation of violence was also highlighted. This necessitates a multidimensional approach to reduce school violence in the ECP.

The atypical and stereotypical portrayal of the wide variety of acts of violence by perpetrators from within and outside the education system creates the impression that school violence in the ECP is endemic. Yet, research by Burton and Leoschut (2013) has shown that the ECP is only one of two provinces where the provincial victimisation rates were less than the $22 \%$ national average, namely $17.7 \%$. Research by Burton and Leaoschut (2013) additionally reveal that South African schools are relatively safe places. The overwhelming majority of learners who took part in their nationwide study, namely $95 \%$, indicated that they felt safe all $(79 \%)$ or most (16\%) of the time. Only $4.6 \%$ of ECP learners indicated that they never feel safe at school. In De Wet's (2003) ECP survey $14.42 \%$ of the educator-respondents indicated that they "most definitely" feel unsafe in their respective schools. Note should thus be taken of Gorelick's (in Robertson, 1998:62) warning that "news by its nature covers the unusual and infrequent. So, almost any story runs the risk of making it seems like the incident described in the story occurs more often than it does". We should therefore not only study and implement guidelines by Burton and Leaoschut (2013), SACE (2011) and the SAHRC (2008) on how to reduce school violence, but also learn from the many schools in the ECP where learners and educators are safe and use these schools as benchmarks for keeping all learners and educators safe.

\section{References}

Adkin, A. (2007). Violent pupils terrorising Mandela Bay bus drivers. The Herald, 23 March, 1.

Astor, RA., Benbenishty, R., Vinokur, AD. \& Zeira, A. (2006). Arab and Jewish elementary school students' perceptions of fear and school violence: understanding the influence of school context. British Journal of Educational Psychology, 76, 91-118.

Barnes, AK. (2010). Die uitwerking van skoolkultuur en -klimaat op geweld in Oos-Kaapse skole: 'n onderwysbestuursperskpektief. PhD dissertation. Bloemfontein: University of the Free State.

Burton, P. (2008). Merchants, skollies ad stones. Experiences of school violence in South Africa. Cape Town: Centre for Justice and Crime Prevention.

Burton, P. \& Leoschut, L. (2013). School violence in South Africa. Results of the 2012 National School Violence Study. Cape Town: Centre for Justice and Crime Prevention.

De Waal, J., Currie, I. \& Erasmus, G. (2000). The Bill of Rights Handbook. $3^{\text {rd }}$ ed. Kenwyn: Juta \& Co.

De Wet, NC. (2003). Eastern Cape educators' perceptions of the causes and the scope of school violence. Acta Criminologica, 16(3), 89-106.

De Wet, NC. (2009). Newspapers' portrayal of school violence in South Africa. Acta Criminologica, 22(1), 46-67.

De Wet, NC. (2011). The Krugersdorp samurai sword killing: a media analysis. Acta Academica, 43(3), 132-165.

Dimbaza, S. (2009). Boy shot in school fight over cellphone. The Herald, 10 November, 1.

Henry, R. (2007). Violence mars school's return. The Herald, 22 January, 7.

Jack, M. (2008). Angry parents order children out of classrooms at Bay school. The Herald, 5 September, 5.

Jack, M. (2006). Teen fights for his life after school stabbing. The Herald, 18 October, 1.

Jacobs, L. (2012). School violence: A multidimensional educational nemesis. PhD dissertation. Bloemfontein: University of the Free State.

Jacobs, L. (2014). Framing of school violence in the South African printed media - (mis)information to the public. South African Journal of Education, 34(1), 1-16.

Kantola, J., Norocel, OC., \& Repo, J. (2011). Gendering violence in the school shootings in Finland. European Journal of Women's Studies, 18(2), 183-197.

Kollapen, J. (2006). Violence threatens right to learn. The Herald, 8 December, 8.

Leavy, P. \& Maloney, KP. (2009). American reporting of school violence and 'people like us'. A comparison of newspaper coverage of the Columbine and Red Lake school shootings. Critical Sociology, 35(2), 273-292.

Masondo, S. (2006). Sadtu slams violence in schools after girl's death. The Herald, 18 May, 3.

Matavire, M. (2003). Councillor condemns Framesby's thug pupils. The Herald, 12 December, 3.

Matomela, D. (2009). Khanyisa boarders left to own devices with school closure. The Herald, 9 February, 5.

Matomela, D. (2008a). Expulsions rise as school violence escalates. The Herald, 29 May, 10.

Matomela, D. (2008b). Chaos as pupils buy 'power to become invincible'. The Herald, 2 December, 1. 
Matyu, J. (2007). School violence blamed on ban of corporal punishment. The Herald, 3 October, 8.

Matyu, J. (2005). Pupils in bloody skirmish over classrooms. The Herald, 20 May, 9.

Matyu, J. (2002a). Protest against crime at schools. The Herald, 9 May, 8.

Matyu, J. (2002b). Vandalism, violence in schools may result in Sadtu strike. The Herald, 6 November, 1.

Mbabela, Z.,Williams, L. \& Reyneke, D. (2012). 'Watch us send your broken promises up in flames'. The Herald, 10 May, 1.

McCabe, J. (2007). Alarm as two H'dorp pupils stabbed by classmates, The Herald, 29 August, 2.

Mills, M. \& Keddie, A. (2010). Cultural reductionism and the media: polarising discourses around schools, violence and masculinity in an age of terror. Oxford Review of Education, 36(4), 427-444.

Mkhize, S.,Gopal, N. \& Colling, SJ. (2012). The impact of community violence on learners: a study of a school in the Swayima rural area. Acta Criminologica, 1, 38-45.

Menifield, CE. (2001). The media's portrayal of urban and rural school violence: a preliminary analysis. Deviant Behavior: An Interdisciplinary Journal, 22, 447-464.

Merriam, SB. (2009). Qualitative research. A guide to design and implementation. San Francisco: Jossey-Bass Publishers.

Mofemele, N. (2007). Appeal to cops for help after spate of violence. The Herald, 18 January, 4.

Muncie, J. (2012). Youth \& crime. $3^{\text {rd }}$ ed. London: Sage Publications.

Ndabeni, K. (2009). Two pupils hurt in gang violence. The Herald, 23 October, 1.

Nieuwenhuis, J. (2007). Analysing qualitative data. In: K. Maree (Ed.), First steps in research (pp. 100-121). Pretoria: Van Schaik.

Nofemele, N. (2006). H'dorp school in shock after stabbing of pupil. The Herald, 19 October, 1.

Rank, F. (2005). School, club rugby violence link probe. The Herald, 9 May, 10.

Roelf, W. \& Sonjica, N. (2006). 'Our schools are war zones'. The Herald, 29 September, 1.

Robertson, L. (1998). When children kill children. American Journalism Review, September, 56-61.

SACE (South African Council of Educators). (2011). School based violence. Centurion: SACE.

SAHRC (South African Human Rights Commission). (2008). Report on the public hearing on school-based violence. [Online] Available: http.www.sahrc.org.za (October 10, 2008).

Spies, D. (2006). Classroom row turns violent, boy in hospital. The Herald, 13 September, 6.

Strawhacker, JT. (2002). School violence: an overview. The Journal of School Nursing, 18(2), 68-72.

The Herald. (2006). Community must act on schools, 23 November, 8.

Timse, T. (2006). 'Acceptance fuels flames of violence in schools'. The Herald, 16 October, 1.

Van der Merwe, N. (2010). A qualitative study on the pro-violence attitudes among learners in South Africa. Acta Criminologica, 1, 107125.

Van der Westhuizen, CN. \& Maree, JG. (2009). The scope of violence in a number of Gauteng schools. Acta Criminologica, 22(3), 4362.

Van Jaarsveld, L. (2008). Violence in schools: a security problem? Acta Criminologica, 2, 175-188.

Wilson, G. (2012). Department to probe U'hage school brawl. The Herald, 25 January, 6.

Wilson, G. \& Matomela, D. (2010). Exam violence grows as tyres burnt, cars stoned. The Herald, 15 September, 1. 